\title{
APLIKASI MOBILE LEARNING JURUSAN MULTIMEDIA BERBASIS ANDROID PADA SMK 1 ANJATAN INDRAMAYU
}

\author{
Desi Dwi Nawang Wulan', Abdurahman Fauzi² \\ 1 Universitas Adhirajasa Reswara Sanjaya \\ e-mail: desydwi69@gamil.com \\ ${ }^{2}$ Universitas Adhirajasa Reswara Sanjaya \\ e-mail: abdurahman.auz@ars.ac.id
}

\begin{abstract}
Abstrak
Perkembangan dunia teknologi dan informasi begitu sangat cepat hingga merambat ke dunia pendidikan. Berbagai perpaduan antara kurikulum baru yang diiringi dengan kemajuan teknologi dapat memberikan terobosan baru di dunia pendidikan untuk lebih meningkatkan efektifitas kegiatan belajar mengajar. Hal itulah yang perlu diadakan di setiap sekolah demi meningkatkan tujuan pembelajaran. SMKN 1 Anjatan adalah salah satu sekolah menengah Kejuruan Negeri yang terletak di kabupaten Indramayu, Jawa Barat yang masih menggunakan pembelajaran manual. Tujuan dari penelitian ini adalah untuk membantu pihak guru dalam mengembangkan kreatifitas siswa meskipun siswa tidak berada di sekolah yang nantinya dapat diharapkan sebagai salah satu sistem yang dapat mengefektifkan kegiatan belajar mengajar. Penelitian ini menggunakan metode perancangan perangkat lunak SDLC (System Development Life Cycle) waterfall yang mempunyai lima tahap yaitu Analisa Kebutuhan, Desain, Pembuatan Kode, Integrasi dan Pengujian, Support dengan menggunakan pemodelan UML (Unified Modeling Language) dan Android Studio dengan bahasa pemrograman java sebagai pembuatan aplikasinya. Penelitian ini menghasilkan dua buah aplikasi yang bisa digunakan oleh guru dan siswa dengan berbagai fitur dan interface yang sangat mudah digunakan dalam kegiatan belajar mengajar.
\end{abstract}

Kata Kunci: Mobile Learning, SDLC Waterfall, Android

\begin{abstract}
The development of the world of technology and information is so fast that it has spread to the world of education. Various combinations of the new curriculum accompanied by technological advances can provide new breakthroughs in the world of education to further increase the effectiveness of teaching and learning activities. That is what needs to be held in every school in order to improve learning objectives. SMKN 1 Anjatan is one of the State Vocational high schools located in Indramayu district, West Java which still uses manual learning. The purpose of this study is to assist the teacher in developing student creativity even though students are not in school which can be expected as a system that can streamline teaching and learning activities. This research uses the SDLC (System Development Life Cycle) waterfall software design method which has five stages, namely Needs Analysis, Design, Code Generation, Integration and Testing, Support using UML (Unified Modeling Language) modeling and Android Studio with the Java programming language as making the application. This study produced two applications that can be used by teachers and students with various features and interfaces that are very easy to use in teaching and learning activities.
\end{abstract}

Keyword: Mobile Learning, SDLC Waterfall, Android

Naskah diterima 15 Januari 2021; direvisi 6 Februari 2021; diterbitkan 28 Februari 2021 


\section{Pendahuluan}

Pengembangan teknologi yang begitu sangat cepat telah menciptakan terobosan-terobosan baru dalam dunia pendidikan. Menurut Aminoto dan Pathoni dalam jurnalnya menyebutkan bahwa seiring dengan perkembangan tersebut metode pembelajaran juga banyak mengalami perkembangan, baik metode pembelajaran secara personal, media pembelajaran ataupun proses pembelajaran (Desmayadi \& Firmansyah, 2019). Pembelajaran itu sendiri pada awalnya hanya berpaku pada pertemuan murid dan siswa yang membahas sebuah materi berbentuk fisik atau cetak. Seiring dengan perkembangannnya, ketika teknologi informasi dan komunikasi telah merambat ke dunia pendidikan maka sistem pembelajaranpun semakin meningkat. Peran buku cetak bahkan guru bisa digantikan dengan perangkatperangkat teknologi komunikasi bergerak dan teknologi internet yang memungkinkan pembelajaran bisa dilakukan secara mobile atau yang biasa disebut dengan mobile learning (m-learning/morning).

Menurut Darmawan dalam jurnalnya mobile learning adalah salah satu alternative bahwa layanan pembelajaran harus dilaksanakan dimana pun dan kapan pun (Aripin, 2018). Dalam hal ini bisa diartikan mobile learning merupakan suatu pendekatan yang melibatkan perangkat bergerak seperti laptop, tablet PC, telepon genggam atau smartphone dimana pelajar bisa mengakses suatu materi berbentuk offline maupun online dan bisa memahami materi tanpa adanya guru atau pembimbing dimanapun dan kapanpun yang mereka butuhkan. Adanya mobile learning ini pelajar dapat belajar sendiri dengan mengakses sebuah aplikasi yang telah menyediakan panduan materi pelajaran yang disertai dengan latihan-latihan soal yang bisa menguji tingkat kemampuan berpikir dari pelajar. Selain itu pelajar juga dapat menghemat biaya karena tidak perlu lagi mencetak atau memfotokopi modul pelajaran.

SMKN 1 Anjatan Indramayu merupakan salah satu sekolah menengah kejuruan yang menjadi tempat dilaksanakannya penelitian. Biasanya sekolah menengah kejuruan ketika berada di kelas 2 maka akan mendapatkan tugas Praktek Kerja Lapangan (PKL) yang mengharuskan siswanya melakukan magang disebuah perusahaaan atau instansi luar sekolah selama minimal 3 bulan. Oleh sebab itu proses belajarmengajar pun akan terganggu dan sangat sulit dilakukan ketika sedang melakukan tugas PKL tersebut. Adanya aplikasi mobile learning ini maka siswa dapat dengan mudah untuk melakukan pemahaman tentang materi pelajaran yang seharusnya dilakukan di sekolah bisa dilakukan ketika sedang melakukan PKL yang berada di luar sekolah. Akan tetapi sebagai penunjang untuk mendukung proses pembelajaran tersebut sekolah ini belum memiliki fasilitas untuk mewujudkan adanya aplikasi mobile learning yang menjadi salah satu alternatif keberhasilan proses belajar-mengajar.

Melihat keadaan yang telah digambarkan pada paragraf sebelumnya, penulis terdorong untuk merancang suatu sistem pembelajaran mobile learning yang diperuntukkan untuk Jurusan Multimedia sebagai media pembelajaran yang bersifat portable dan dapat digunakan dimanapun dan kapanpun. Dibalik itu semua, tujuan penulis untuk membuat aplikasi mobile learning kelas 2 Jurusan Multimedia untuk mengakomodasi dan memfasilitasi siswa kelas 2 Jurusan Multimedia SMK dalam mempelajari materi Produktif atau Dasar Bidang Keahlian. Diharapkan melalui aplikasi mobile learning ini, dapat menjadi media pembelajaran alternatif yang sifatnya praktis dapat digunakan siswa dimanapun dan kapanpun serta dapat membantu dalam meningkatkan tingkat pemahaman dan kekreatifan siswa.

\section{Manfaat Penelitian}

Manfaat dari penelitian ini adalah:

1. Siswa dapat mempelajari mata pelajaran produktif melalui smarthphone kapanpun dan dimanapun.

2. Pembelajaran bisa lebih efektif meskipun siswa sedang melaksanakan Praktek Kerja Lapangan yang mengharuskan diluar sekolah dalam beberapa bulan.

3. Penghematan kertas yang merubah modul fisik ke digital.

4. Siswa dapat lebih mandiri dalam memahami materi meskipun jauh dengan guru/pembimbing di sekolah.

\section{Perancangan Sistem}

Secara umum perancangan sistem adalah suatu tahap dimana didalamnya terdapat identifikasi komponen-komponen sistem informasi yang akan dirancang 
secara rinci, yang bertujuan untuk memberikan gambaran kepada pengguna mengenai sistem yang baru

\section{LRS (Logical Record Structure)}

Logical Record Structure (LRS) digambarkan kotak persegi panjang dan dengan nama yang unik. File record pada LRS ditempatkan dalam kotak. LRS terdiri dari link diantara tipe record lainnya, banyaknya link dari LRS yang diberi nama oleh field-field yang kelihatan pada kedua link tipe record (Sukmaindrayana \& Sidik, 2017).

\section{ERD (Entity Relationship Diagram)}

Menurut Fridayanthie (2015) ERD (Entity Relationship Diagram) adalah model Teknik pendekatan yang menyatakan atau menggambarkan hubungan suatu model. Didalam hubungan ini tersebut dinyatakan yang utama dari ERD adalah menunjukan objek data (Entity) dan hubungan (Relationship), yang ada pada Entity berikutnya.

\section{UML (Unified Modeling Language)}

Menurut Rosa dan Shalahuddin dalam jurnal E. W. Fridayanthie \& Mahdiati (2016) UML (Unified Modeling Language) adalah salah satu standar bahasa yang banyak digunakan di dunia industri untuk medefinisikan requirement, membuat analisis dan desain, serta menggambarkan arstitektur dalam pemograman berorientasi objek.

\section{Use Case Diagram}

Use case mendeskripsikan sebuah interaksi antara satu atau lebih actor dengan sistem informasi yang akan dibuat. Secara kasar use case dibuat untuk mengetahui fungsi apa saja yang ada di dalam sebuah sistem informasi dan siapa saja yang berhak menggunakan fungsi fungsi itu (Hidayatulloh \& Muttaqin, 2019).

Pada penelitian ini terdapat dua user yaitu Guru dan Siswa yang masing-masing dari user memiliki aplikasi yang terpisah.

\section{Class Diagram}

Diagram kelas atau class diagram menggambarkan struktur sistem dari segi pendefisian kelas-kelas yang akan dibuat untuk membangun sistem. Kelas memiliki apa yang disebut atribut dan method atau operasi(Hidayatulloh \& Muttaqin, 2019).

\section{Activity Diagram}

Menurut Rosa dan Shalahuddin dalam jurnal (Fridayanthie \& Mahdiati, 2016) diagram aktivitas atau activity diagram menggambarkan workflow (aliran kerja) atau aktivitas dari sebuah sistem atau proses bisnis atau menu yang ada pada perangkat lunak.

\section{Sequence Diagram}

Sequence diagram menggambarkan kolaborasi dinamis antara sejumlah object. Kegunaannya untuk menunjukkan rangkaian pesan yang dikirim antara object juga interaksi antara object, sesuatu yang terjadi pada titik tertentu dalam eksekusi sistem (Pratama, 2019).

\section{Firebase}

Database yang digunakan dalam aplikasi ini adalah Firebase yang digunakan untuk menyimpan dan mengolah data pengguna serta interaksi yang dilakukan antar pengguna. Menurut Syukri \& Setiawan dalam Suparman \& Arifin (2017) firebase adalah layanan DbaaS (Database as a Service) dengan konsep real time. Firebase merupakan penyedia layanan cloud dengan backend sebagai service.

\section{Black Box Testing}

Menurut Cholifah et al. (2018) Metode Blac kbox Testing merupakan salah satu metode yang mudah digunakan karena hanya memerlukan batas bawah dan batas atas dari data yang mengharapkan, Estimasi banyaknya data uji dapat dihitung melalui jumlah bidang entri data yang akan diuji, aturan entri yang harus dipenuhi serta kasus batas atas dan batas bawah yang memenuhi.

\section{Metode Penelitian}

Metode pengumpulan data yang digunakan pada penelitian ini adalah :

1. Wawancara

Penulis pada tahap ini melakukan wawancara dengan Kepala Program Studi Multimedia sebagai guru dan kepala jurusan multimedia SMKN 1 Anjatan.

\section{Studi Pustaka}

Penulis melakukan penelitian dengan mencari sumber-sumber dari buku, jurnal, dan situs web resmi yang berkenaan dengan proses pekerjaan tersebut.

\section{Metode Perancangan}

Proses perancangan perangkat lunak pada penelitian ini menggunakan metode SDLC (System Development Life Cycle) waterfall. Menurut Sukamto dan Shalahuddin dalam Firmansyah \& Udi (2017) SDLC atau System Development Life Cycle adalah proses mengembangkan atau mengubah suatu sistem perangkat lunak dengan menggunakan model-model dan metodologi yang digunakan orang untuk mengembangkan sistem-sistem 
perangkat lunak sebelumnya, berdasarkan best practice atau cara-cara yang sudah teruji baik. Metode ini memiliki pendekatan secara sistematis mulai dari analisis, desain, pengkodean, pengujian dan tahap pendukung. Berikut penjelasan pada setiap tahapan yang dilakukan oleh penulis:

1. Analisis Kebutuhan (requirements analysis)

Analisis kebutuhan sistem pada tahap ini yaitu terdapat form register, form login, form menu yang melampirkan pilihan mata pelajaran, form list materi dari masing-masing mata pelajaran, form tambah tugas, form ubah dan hapus tuga, form, dan form profil.

2. Desain (design)

Desain dalam tahap ini yaitu menggunakan LSR, ERD dan UML.

3. Pembuatan Code (Code Generation) Pembuatan code pada tahap ini menggunakan bahasa pemrograman java.

4. Integrasi dan Pengujian (Integration \& Testing)

Integrasi dan pengujian dalam tahap ini menggunakan black box testing.

5. Pendukung (Support)

Software yang digunakan untuk merancang aplikasi ini yaitu Android Studio, dan Firebase.

\section{Hasil dan Pembahasan}

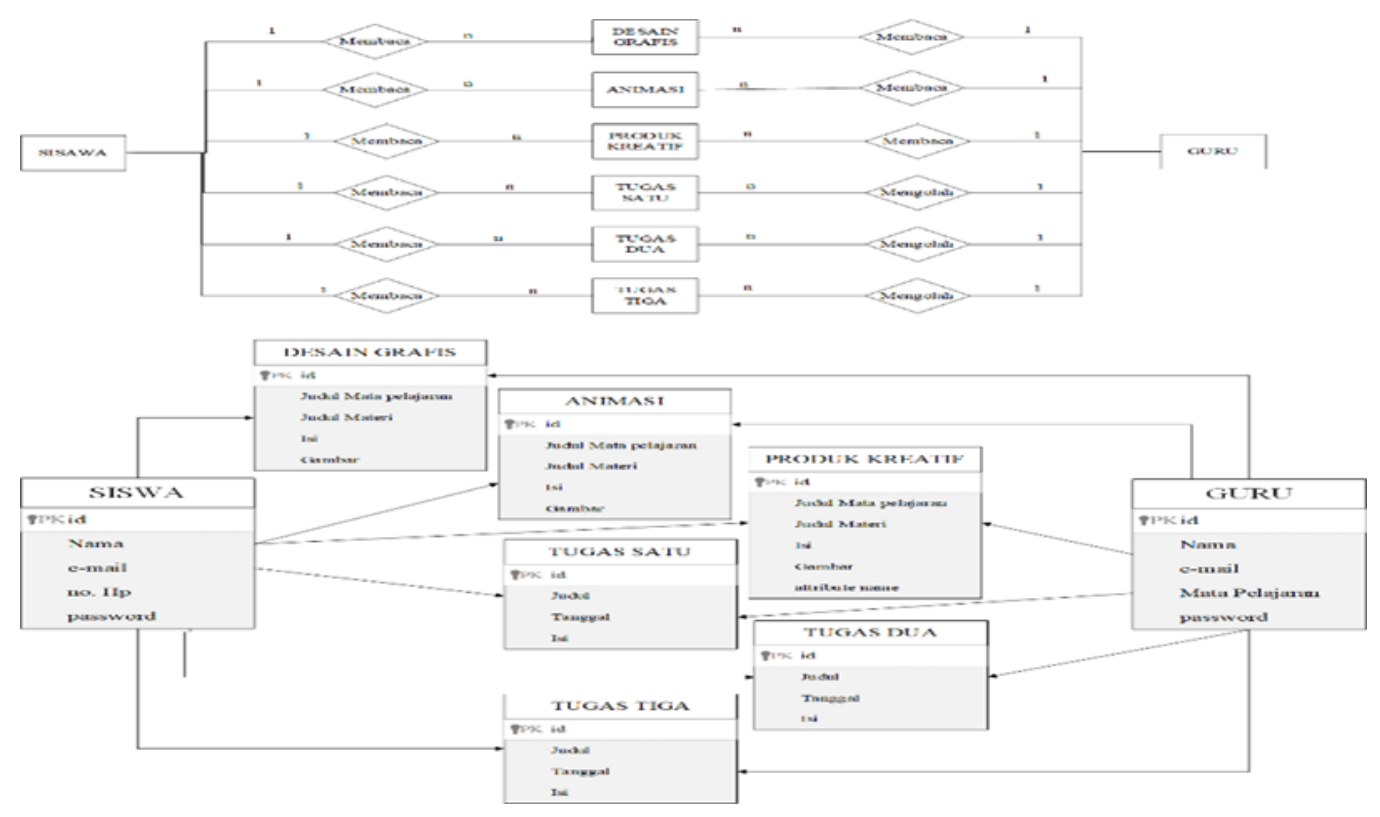

Gambar 1. LRS (Logical Record Structure)
Setelah melakukan analisa sistem, perancangan sistem dan berakhir dengan pembuatan program yang sesungguhnya, maka hasil yang dicapai oleh penulis adalah dua buah Aplikasi Mobile Learning Jurusan Berbasis Android pada SMKN 1 Anjatan Indramayu yang diperuntukkan siswa dan guru dengan menggnakan bahasa pemrograman java dan xml sebagai desain halaman layout, dan Firebase sebagai penyimpanan data atau databasenya.

Aplikasi Mobile Learning Jurusan Multimedia Berbasis Android pada SMKN 1 Anjatan Indramayu bermanfaat untuk guru agar mempermudah mendidik siswa dalam sebuah media belajar mata pelajaran Produktif (Dasar Bidang Keahlian) dan dapat dengan mudah memberikan tugas untuk meningkatkan kreatifitas siswa dalam mengembangkan keahliannya. desain halaman layout, dan Firebase sebagai penyimpanan data atau databasenya. Aplikasi Mobile Learning Jurusan Berbasis Android pada SMKN 1 Anjatan Indramayu juga sangat bermanfaat bagi siswa karena sangat membantu ketika siswa sedang tidak berada di lingkungan sekolah agar dapat tetap mempelajari materi pelajaran meskipun sedang tidak bersama guru.

\subsection{LRS (Logical Record Structure)}

Dari hasil analisa dan perancangan, dapat digambarkan Logical Record Structure sebagai berikut: 


\subsection{ERD (Entity Relationship Diagram)}

Dari hasil analisa dan perancangan, dapat digambarkan Entity Relationship Diagram sebagai berikut:

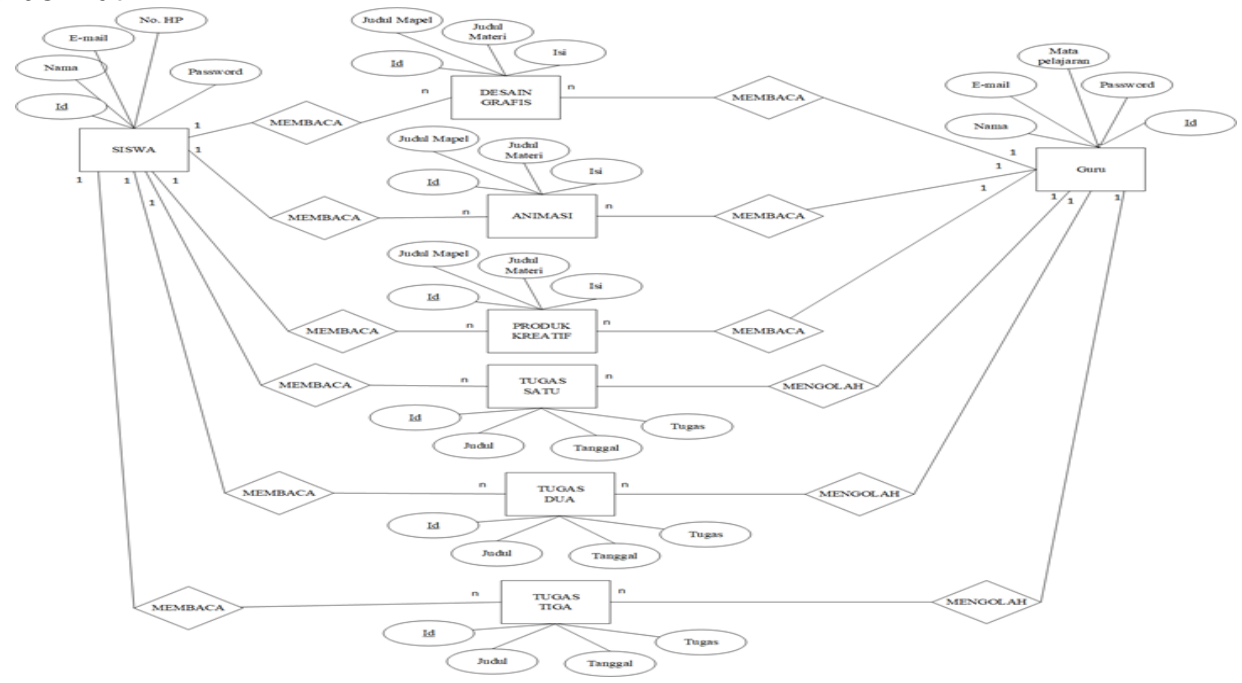

Gambar 2. ERD (Entity Relationship Diagram)

3.3. UML (Unified Modeling Language)

Dari hasil analisa dan perancangan, dapat digambarkan masing-masing diagram sebagai berikut:

\section{Use Case Diagram}

A. Use Case Diagram Guru
Hasil dari perancangan bahwa pada penelitian ini menghasilkan dua buah user yaitu guru dan siswa dan masing-masing user memiliki aplikasi yang terpisah tetapi saling berhubungan. Berikut use case diagraminya:



Gambar 3. Use Case Diagram Guru

B. Use Case Diagram Siswa

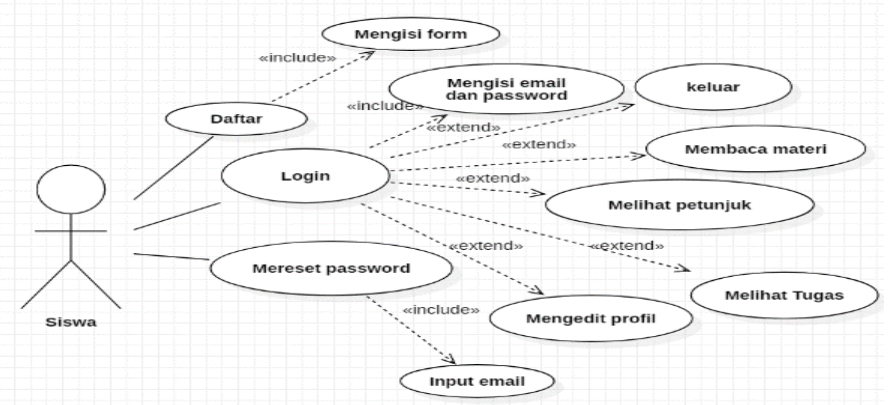

Gambar 4. Use Case Diagram Siswa 


\section{Activity Diagram}

Berikut adalah Activity Diagram yang dihasilkan dari perancangan penelitian ini:

A. Activity Diagram

1) Activity Diagram Login



Gambar 5. Activity Diagram Login

$\mathrm{Di}$ activity diagram ini, user memasukkan email dan password dan klik tombol masuk lalu sistem akan memvalidasi ke database apakah data yang dimasukkan oleh siswa sesuai atau tidak.

1) Activity Diagram Register

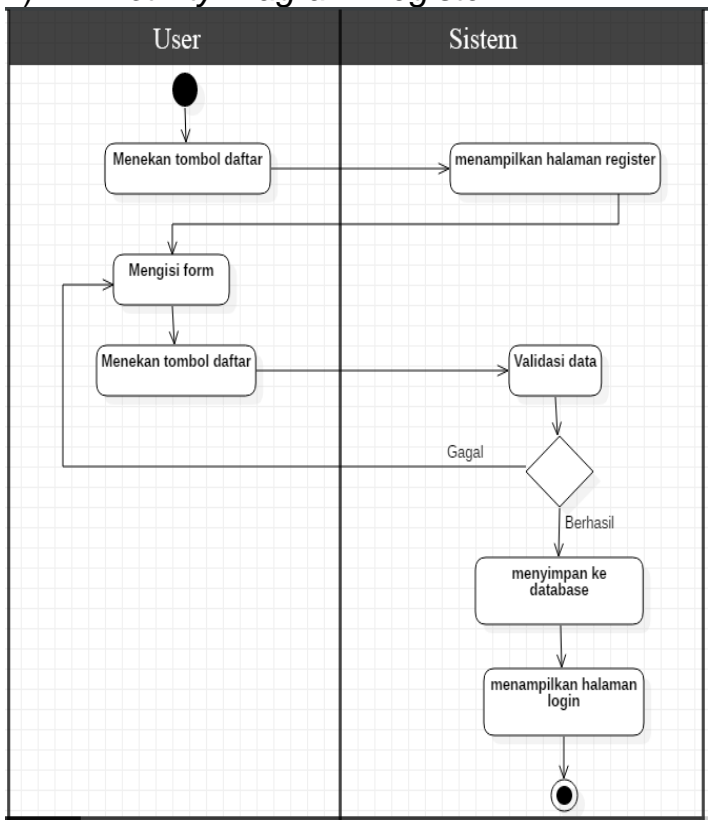

Gambar 6. Activity Diagram Register

$\mathrm{Di}$ halaman register maka user akan memasukkan data nama, email, no. HP dan password.
2) Activity Diagram Membaca Materi

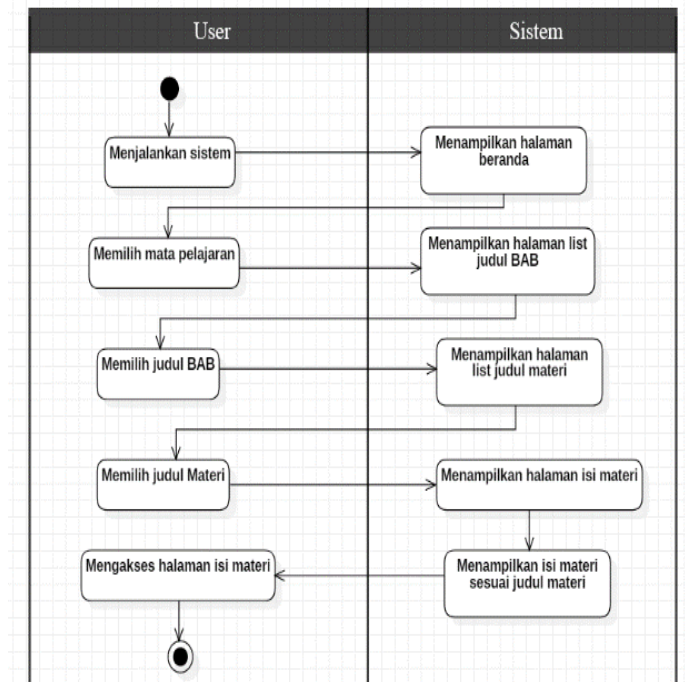

Gambar 7. Activity Diagram Membaca Materi

Pada activity diagram ini,user dapat memilih mata pelajaran yang sesuai kemudian sistem akan menampilkan materi yang akan dibaca

3) Activity Diagram Lihat Tugas

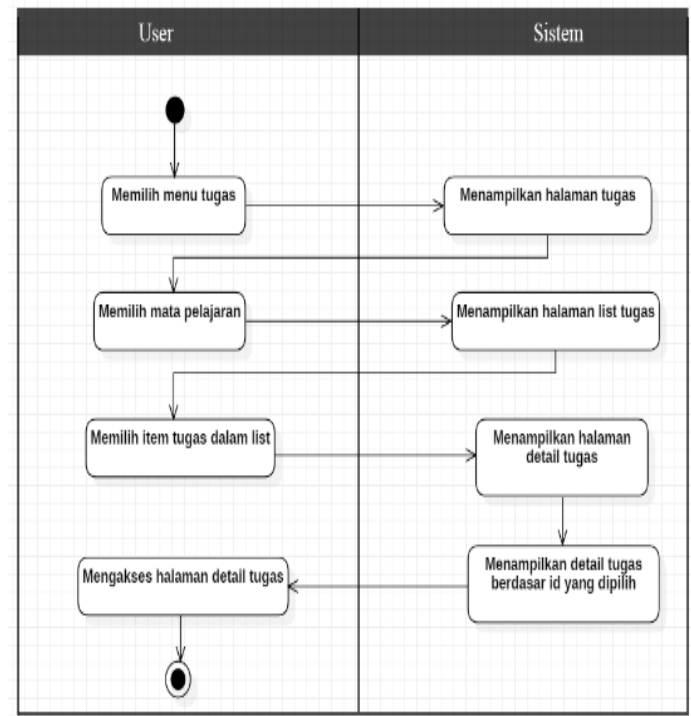

Gambar 8. Activity Diagram Lihat

Tugas Siswa

Pada activity diagram ini,siswa memilih item tugas yang ada di list, kemudian sistem akan menampilkan detail tugas di halaman detail tugas. 
2) Activity Diagram Tambah Tugas

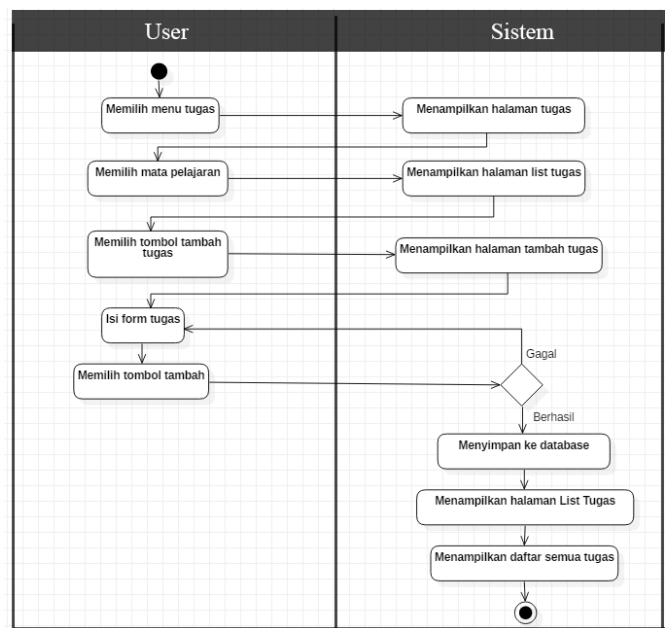

Gambar 9. Activity Diagram Tambah Tugas

Pada activity diagram tambah tugas ini, guru akan menambahkan tugas sesuai dengan materi yang telah dipelajari, yang disimpan di database dan kemudian bisa diakses oleh siswa dan ditampilkan di aplikasi untuk siswa.

\section{Class Diagram}

Berikut adalah adalah class diagram yang di rancang pada aplikasi mobile learning Jurusan Multimedia:

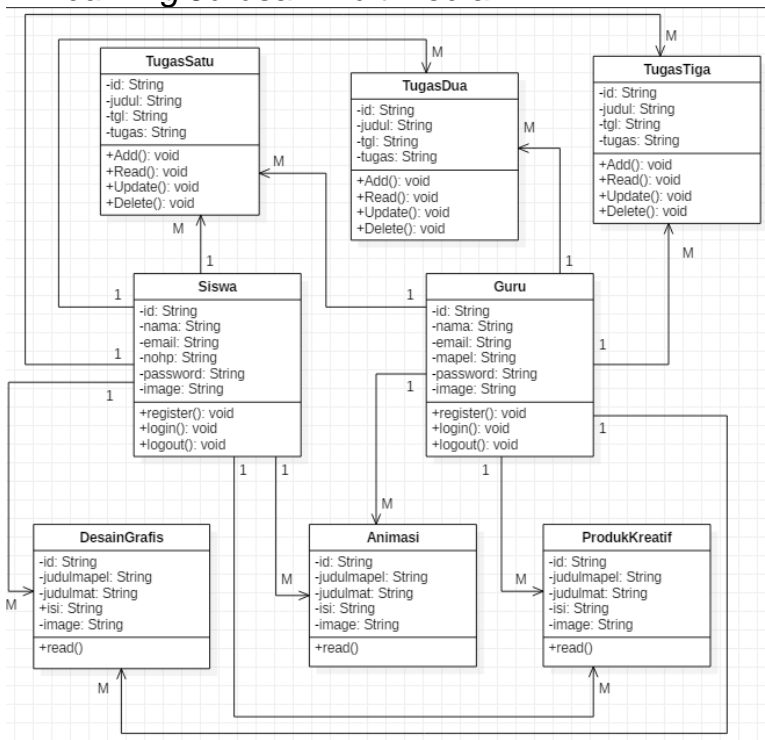

Gambar 10. Class Diagram

\subsection{Implementasi}

Aplikasi Mobile Learning Jurusan Multimedia Berbasis Android pada SMKN 1 Anjatan Indramayu ini mempunyai dua aplikasi yang terpisah, yaitu untuk guru dan siswa.
1. Tampilan Halaman Login

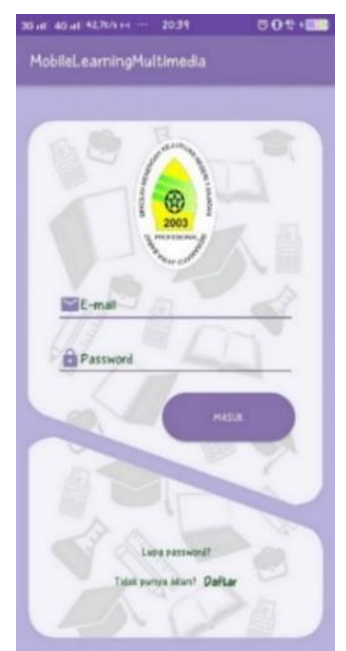

Gambar 11. Interface Login

2. Tampilan Halaman Register

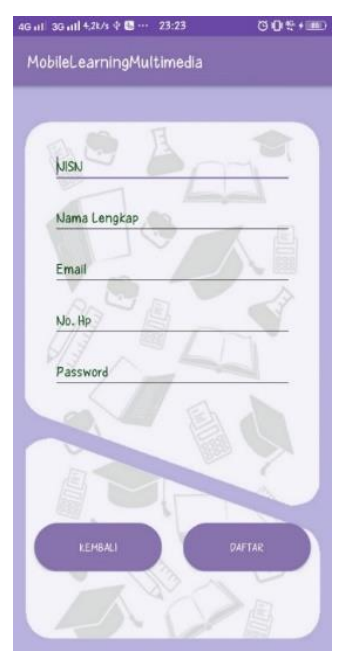

Gambar 12. Interface Register

3. Tampilan Halaman Beranda

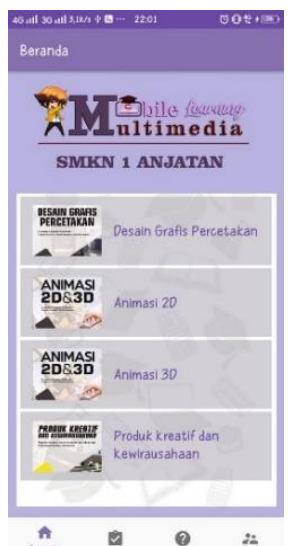

Gambar 13. Interface Halaman Beranda http://ejurnal.ars.ac.id/index.php/jti 
4. Tampilan Halaman Isi Materi



Gambar 14. Interface Halaman Isi Materi

5. Tampilan Halaman Detail Tugas

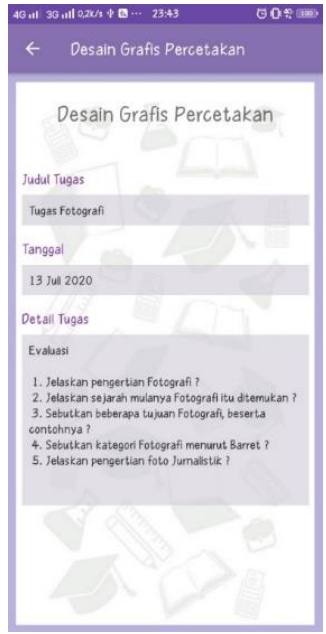

Gambar 15. Interface Halaman Detail Tugas

6. Tampilan Halaman Profil

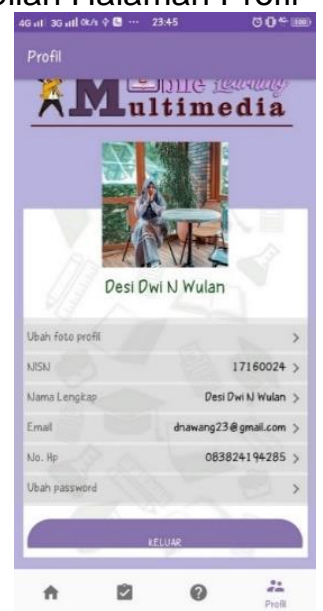

Gambar 16. Interface Halaman Profil
7. Tampilan Halaman List Tugas

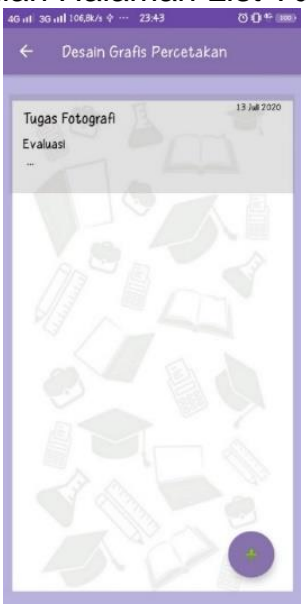

Gambar 17. Interface Halaman List Tugas

8. Tampilan Halaman Tambah Tugas

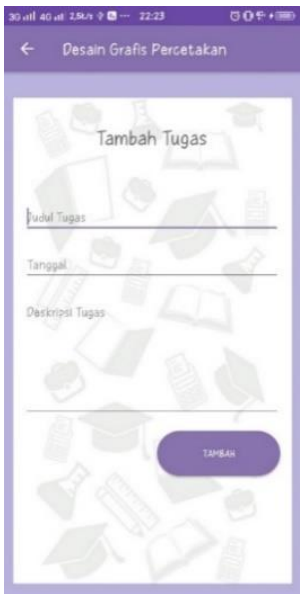

Gambar 18. Interface Halaman Tambah Tugas

9. Tampilan Halaman Ubah dan Hapus Tugas

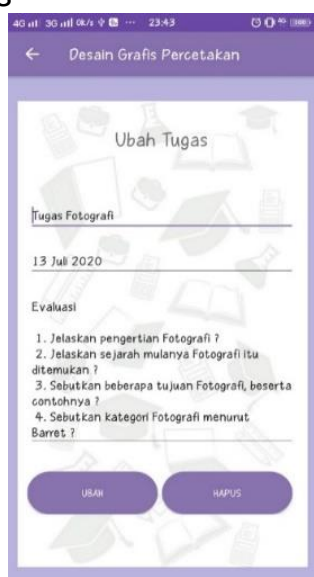

Gambar 19. Interface Halaman Tambah Tugas

http://ejurnal.ars.ac.id/index.php/jti 


\subsection{Hasil Pengujian}

Pengujian adalah hal penting dalam siklus rekayasa perangkat lunak. Tujuan utamanya adalah menjamin perangkat lunak dapat digunakan oleh user, memiliki kualitas dan dapat memenuhi kebutuhan dari pengguna program aplikasi. Pengujian kali ini dilakukan dengan metode pengujian black box. Berikut hasil pengujian yang telah dilakukan dengan black box testing.

Tabel 1. Hasil Pengujian User Siswa

\begin{tabular}{|l|l|l|}
\hline No. & Model Pengujian & Hasil \\
\hline 1 & Login Siswa & Valid \\
\hline 2 & Register Siswa & Valid \\
\hline 3 & Lupa Password Siswa & Valid \\
\hline 4 & Lihat Materi & Valid \\
\hline 5 & Lihat Tugas & Valid \\
\hline 6 & Lihat Petunjuk & Valid \\
\hline 7 & Profil & Valid \\
\hline
\end{tabular}

Tabel 2. Hasil Pengujian User Guru

\begin{tabular}{|l|l|l|}
\hline No. & Model Pengujian & Hasil \\
\hline 1 & Login Guru & Valid \\
\hline 2 & Register Guru & Valid \\
\hline 3 & Lupa Password Guru & Valid \\
\hline 4 & Lihat Materi & Valid \\
\hline 5 & Tambah Tugas & Valid \\
\hline 6 & Ubah Tugas & Valid \\
\hline 7 & Hapus Tugas & Valid \\
\hline 8 & Lihat Petunjuk & Valid \\
\hline 9 & Profil & Valid \\
\hline
\end{tabular}

\section{Kesimpulan}

Berdasarkan penelitian yang telah dilakukan dan telah diuraikan dalam laporan tentang pembuatan teknologi pembelajaran produktif jurusan multimedia kelas 2 SMK, dengan ini maka dapat disimpulkan beberapa hal sebagai berikut:

1. Proses perancangan aplikasi mobile learning jurusan multimedia kelas 2 SMK dilakukan dengan lima tahapan prosedur, yaitu pertama Analisa Kebutuhan, kedua Desain, ketiga Pembuatan Kode, keempat Integrasi dan Pengujian, dan yang kelima Support.
2. Aplikasi mobile learning jurusan multimedia tingkat sekolah menengah kejuruan ini dengan menggunakan Platform Android dengan bahasa pemrograman java.

3. Dengan adanya aplikasi Mobile Learning Multimedia berbasis android ini bisa membantu proses kegiatan belajar mengajar untuk siswa khususnya siswa yang sedang melakukan Praktek Kerja Lapangan yang mengharuskan tidak adanya KBM di dalam kelas.

Saran

Pada program aplikasi yang telah dibangun, penulis memberikan beberapa saran terhadap pengembangan dari aplikasi tersebut, diantaranya sebagai berikut:

1. Untuk ke depannya, aplikasi pembelajaran ini bisa dikembangkan dengan menambahkan fitur notifikasi kepada siswa ketika guru telah menambahkan tugas baru.

2. Pada tahap pengembangan selanjutnya diharapkan kualitas dan kuantitas interface materi dapat ditingkatkan dengan menambahkan fitur tambahan.

3. Pada pengembangan selanjutnya, diharapkan terdapat menu nilai ketika siswa telah mengerjakan soal latihan.

\section{Referensi}

Aripin, I. (2018). Konsep Dan Aplikasi Mobile Learning Dalam Pembelajaran Biologi. Jurnal Bio Educatio, 3(1), 01-09. https://www.neliti.com/id/publications/2 79501/konsep-dan-aplikasi-mobilelearning-dalam-pembelajaran-biologi

Cholifah, W. N., Yulianingsih, Y., \& Sagita, S. M. (2018). Pengujian Black Box Testing pada Aplikasi Action \& Strategy Berbasis Android dengan Teknologi Phonegap. STRING (Satuan Tulisan Riset Dan Inovasi Teknologi), 3(2), 206. https://doi.org/10.30998/string.v3i2.304 8

Desmayadi, V., \& Firmansyah, R. (2019). Penerimaan Aplikasi One Qur'an Sebagai Platform Belajar Membaca Qur'an Menggunakan Metode TAM. http://digilib.ars.ac.id/index.php?p=sho w_detail\&id $=4911 \&$ keywords $=$ Penerim aan+Aplikasi+One+Qur\%27an+Sebag ai+Platform+Belajar+Membaca+Qur\% 27an+Menggunakan+Metode+TAM 
Firmansyah, Y., \& Udi, U. (2017). Penerapan Metode SDLC Waterfall Dalam Pembuatan Sistem Informasi Akademik Berbasis Web Studi Kasus Pondok Pesantren Al-Habib Sholeh Kabupaten Kubu Raya, Kalimantan Barat. Jurnal Teknologi Dan Manajemen Informatika, 4(1). https://doi.org/10.26905/jtmi.v4i1.1605

Fridayanthie, E. W., \& Mahdiati, T. (2016). RANCANG BANGUN SISTEM INFORMASI PERMINTAAN ATK BERBASIS INTRANET (STUDI KASUS: KEJAKSAAN NEGERI RANGKASBITUNG). JURNAL KHATULISTIWA INFORMATIKA, 3(1), 56.

https://doi.org/https://doi.org/10.3929/et hz-b-000238666

Fridayanthie, W. E. (2015). Perancangan sistem informasi penjualan peralatan hiking berbasis desktop pada toko cimone outdoor tanggerang. Jurnal Khatulistiwa Informatika, 3(2), 143151.

https://ejournal.bsi.ac.id/ejurnal/index.p $\mathrm{hp} /$ khatulistiwa/article/view/1665

Hidayatulloh, S., \& Muttaqin, Y. R. (2019). PERANCANGAN APLIKASI DESTINASI PUSAT OLEH- OLEH KOTA GARUT BERBASIS ANDROID MENGGUNAKAN FIREBASE DAN GOOGLE MAPS APIS. 1-8. http://digilib.ars.ac.id/index.php?p=sho w_detail\&id $=5243 \&$ keywords=

Pratama, A. R. (2019). Belajar Unified Modeling Language (UML) Pengenalan. https://www.codepolitan.com/unifiedmodeling-language-uml

Sukmaindrayana, A., \& Sidik, R. (2017). Aplikasi Grosir Pada Toko RSIDIK Bungursari Tasimalaya. Jurnal Manajemen Informatika, 4(2), 1-30. https://doi.org/10.1017/CBO978110741 5324.004

Suparman, J., \& Arifin, T. (2017). RANCANG BANGUN APLIKASI SISTEM INFORMASI AKADEMIK DAN NON AKADEMIK SEKOLAH BERBASIS ANDROID MENGGUNAKAN FIREBASE. 1-10. http://digilib.ars.ac.id/index.php?p=sho $w \_$detail\&id $=5248 \&$ keywords $=$ 